\title{
Translating Family Names in Hungarian: A Diachronic Survey ${ }^{1}$
}

\section{Tamás Farkas and Mariann Slíz}

\begin{abstract}
In our paper we focus on the translating practice and translatability of surnames used in Hungarian, from the problems of translating the immediate predecessors of surnames to the questions of translating surnames today. Our main interest is in how multilingualism, language contact situations, language prestige considerations, customs, fashion and other potential factors affect the use of these names in different languages, and the translatability in a wider sense in the actual practice in Hungary and other countries. We shall look at name translation practice in medieval documents, the relevant questions of spontaneous and conscious surname changes, the changes of Hungarian surnames used outside of Hungary, and finally the questions of translating surnames occurring in fiction.
\end{abstract}

Keywords: history of Hungarian family names, translation of personal names, name assimilation, name changes in Hungary, fictional names

Biographies: Tamás Farkas is Senior Lecturer and Director of Studies in the Institute of Hungarian Linguistics and Finno-Ugric Studies at Eötvös Loránd University, Budapest. He received his PhD in 2002, and completed his Habilitation in 2013. His main research interest is onomastics as a field of interdisciplinary studies, especially historical anthroponomastics, socioonomastics and applied onomastics. He has published several papers on the system and the history of Hungarian family names in the framework of dimensional linguistics. He is the secretary of the Society of Hungarian Linguistics, and the editor of Névtani Értesitö, the journal of Hungarian onomastics. His latest major works include Családnév-változtatás Magyarországon [Surname Changes in Hungary] (2009), and Régi magyar családnevek névvégmutató szótára [Reverse Dictionary of Historical Hungarian Family Names] (2009).

Mariann Slíz is Lecturer in the Institute of Hungarian Linguistics and Finno-Ugric Studies at Eötvös Loránd University, Budapest. She received her PhD in 2010. She is the co-editor of Névtani Értesitö, the journal of Hungarian onomastics. Her main research interests are onomastics (especially personal names, name theory and literary names), historical linguistics and cultural history. She has published several articles on historical personal names (mainly on the history of Hungarian family names) and on the use of fictional names. Her latest major works include Személynévadás az Anjou-korban [Naming in the Angevin Age] (2011), Anjou-kori személynévtár (13011342) [A Dictionary of Personal Names in the Angevin Age] (2011), and Személynevek a középkori Magyarországon [Personal Names in the Medieval Hungary] (2011).

${ }^{1}$ This paper was supported by the János Bolyai Research Scholarship of the Hungarian Academy of Sciences.

(cc) EY New articles in this journal are licensed under a Creative Commons Attribution 4.0 International License. 
Farkas, Tamás and Mariann Slíz. "Translating Family Names in Hungarian: A Diachronic Survey.” Hungarian Cultural Studies. e-Journal of the American Hungarian Educators Association, Volume 6 (2013): http://ahea.pitt.edu DOI: 10.5195/ahea.2013.114

\section{The Translatability of Personal Names}

Today the dominant approach to the question of the translatability of personal names in Hungary is that they are not to be translated. In fact, certain types of personal names (e.g. the names of monarchs, popes and saints), if they have a conventional target language equivalent are, in fact, usually translated, e.g. Eng. Henry VIII Hun. VIII. Henrik, It. Papa Giovanni Paolo II Hun. II. János Pál pápa, Sp. Ignacio de Loyola Loyolai Szent Ignác or Loyola Ignác, etc., with translators' practice and the guidelines having undergone considerable changes over the times. Translating foreign first names and using the traditional Hungarian order of the name components (family name + given name, instead of the typical Indo-European given name + family name order) was widespread practice as late as the beginning of the twentieth century (e.g. It. Cristoforo Colombo $\sim$ Hun. Kolumbusz Kristóf, Ger. Martin Luther $\sim$ Hun. Luther Márton, Ger. Karl May Hun. May Károly, Fr. Jules Verne $\sim$ Hun. Verne Gyula). Surnames would usually be spelled with the original orthography (cf. Luther, May), yet in certain cases it was the spelling based on the Hungarian pronunciation of the given name that became prevalent (see e.g. Columbus Kolumbusz, Calvin $\sim$ Kálvin). Today these practices are no longer used, and yet some of the Hungarian versions they generated are still in use, like for Columbus and Calvin, but, for the writers listed above, less and less frequently.

We have our reasons for talking about 'translation practices' in the rendering of foreign names in Hungarian, as 'in a wider sense, we can talk about translating a proper noun in all cases when another equivalent of the proper noun or another denominator for its bearer is used' (J. Soltész 1979: 119). Translation is a special, intercultural and interlingual form of communication, and, consequently, translating names, which is part of the translation process, cannot be a simple question of leaving a name untranslated or translating, but a number of different possible procedures need to be considered, which can be illustrated with all their potential colorfulness by giving the possible Hungarian translations of William Shakespeare's name (cf. Vermes 2005, Farkas 2009a: 23):

(1) Transference: using the name in its original form in the target language text as William Shakespeare, which is the typical solution today. (2) Substitution: (a) Replacing one or more components of the name with its conventional target language equivalent: Shakespeare Vilmos, which was the dominant solution of the nineteenth century. (b) Adapting the name to the pronunciation or orthography of the target language: Sekszpir Vilmos, which was used significantly less frequently; yet this version was used by writer and journalist Jenő Rákosi (1842-1929) and, as a simple Google search will reveal, this version does crop up in today's usage too, regularly with the intention of being archaic, elevated and witty at the same time. (3) Translation in the narrow sense: *Dárdarázó ('shake-spear') Vilmos (here it is a theoretical example, not used in actual texts for translating the playwright's name, though it can be used with humorous intentions (e.g. Eng. George Bush > Hung. Bokor Gyuri, Liz Taylor > Szabó Böske), with names in fiction (e.g. J.R.R. Tolkien's Frodo Baggins > Zsákos Frodó) and was rather common with family name changes (e.g. Germ. Müller > Hun. Molnár, Slavic Nemecz > Hun. Németh). (4) Modification: substantially changing the name itself or replacing it with common nouns, e.g. the Swan of Avon, the great English playwright, where both expressions are suitably narrow in sense in Hungarian to make the referent quite obvious.

The translatability of personal names in all the above senses is a rather complex question, so in the following, we shall narrow the scope of our inquiry to Hungarian surnames and their immediate predecessors. Our main interest is how multilingualism, language contact situations, language prestige considerations and trends, and other factors have affected and continue to 
Farkas, Tamás and Mariann Slíz. "Translating Family Names in Hungarian: A Diachronic Survey.” Hungarian Cultural Studies. e-Journal of the American Hungarian Educators Association, Volume 6 (2013): http://ahea.pitt.edu DOI: 10.5195/ahea.2013.114

affect the use of these names in different languages, and the translatability in a wider sense in the practice in Hungary and other countries throughout their history, including the names of fictitious characters used in literature.

It is to be noted that the use of names whose translation involves transliteration raises a whole set of further (mainly orthographical) questions. Dealing with these, however, would be outside the scope of this paper, both in terms of length and content. Thus, in the following, we shall concentrate on the phenomena of translating names between languages with a Latin-based alphabet and Hungarian in the sense spelled out above.

\section{Translation in the Period of the Formation of Family Names}

The formation of family names in Hungarian was a process that spanned several centuries. From the thirteenth century onwards persons would be denoted using not only given names but longer, specifying circumscriptions. By the end of the thirteenth century, different types of socalled distinguishing elements arose from these descriptors, ones which can be considered the immediate predecessors of family names. The four main types, connected to the given names by Latin linking elements (using examples from the early and mid-fourteenth century) were: (1) filius ('son of X'; less frequently frater 'brother of', nepos 'grandson of' etc.) + the given name of a relative, typically the father e.g. Stephanus filius Michaelis 'Michael's son Stephen' (AO. 5: 143); (2) de ('from X') + name of place of origin or property, e.g. Paulus de Bethlenfalva 'Paul from Bethlenfalva' (AO. 5: 35); (3) de genere ('from genus/clan X') + name of genus, e.g. Achyntus quondam de genere Pese 'the late Jácint from the genus Pöse' (AO. 5: 98); (4) dictus ('called X') + another external or internal characteristic, e.g. Ladislaus dictus Cheh 'Ladislaus called Czech' (AO. 5: 562). One given name could have several distinguishing elements attached to it and the same person could be referred to in different documents using different distinguishing elements (e.g. Petrum Zudor 'Peter Cudar (= ferocious) /accusative/' [AO. 5: 187], Petri dicti Zwdar filii Dominici de Bulch 'to the son of Dominic, Peter called Cudar (= ferocious) who is from Bulcs' [AO. 5: 417]). These elements could not yet be inherited by the next generation but, similarly to nicknames, were only used for the specific individual. During the process of becoming family names, the Latin linking elements gradually vanished, variability decreased and (mostly by the sixteenth and seventeenth centuries) one of the distinguishing elements finally became inheritable by the other closest relatives and their descendants and thus a family name emerged.

The distinguishing elements would initially appear in documents in Latin, but rarely, though gradually more and more regularly, also in the vernacular. Thus, for example, within one and the same expression one of the elements signifying a characteristic could be featurer in Latin, while the other would be in the vernacular, in most cases Hungarian, Lachk dicto Syketh filio Petri magni de Matyuch 'Lack called Siket, son of Peter Nagy from Mátyóc' (AO. 4: 330; Lat. magni 'great/big', Hun. Syketh 'deaf'). As we can see, names of individuals would mostly feature in Latin and the order of the components would also follow the Latin fashion (given name + distinguishing element) in written language. The fact that in living Hungarian usage from the beginning the reverse order was common (distinguishing element + given name) is testified by very rare examples of personal names (Nogmiklous 'Nagy (= great/big) + Nicholas'; AO. 1: 28) and, more frequently, place names containing this usage, e.g. Nogjanusfeldy 'Nagy (= great/big) + János (= John) + földe (= his land)' (AO. 5: 416). This order (family name + given name) can be found in certain Indo-European languages in Europe, e.g. Flemish, and FinnoUgric languages such as Finnish and Estonian, but only in non-official use, while Hungarian is 
Farkas, Tamás and Mariann Slíz. "Translating Family Names in Hungarian: A Diachronic Survey.” Hungarian Cultural Studies. e-Journal of the American Hungarian Educators Association, Volume 6 (2013): http://ahea.pitt.edu DOI: 10.5195/ahea.2013.114

the only European language today, where it is used both officially and non-officially (cf. Farkas 2009b: 28-29).

Translating names into Latin during the Middle Ages and the Early Modern Age was a result of the official nature of the register as well as the status of Latin as a prestige language, which apart from Hungarian and German, less frequently used as an official language in regionally varying degrees, was the dominant official language used throughout the country. 'Official' here only refers to the fact that the document containing a certain name was created during a legal procedure. Translation itself was typically occasional and the arena of its use was restrained to written language, so it had no effect on the actual way of using the name by its bearer, and that is why it could be that the order of the elements of one's name in the Latin register could be Petrus Kowach and yet in the spoken language it was Kovács Péter. Moreover, we find examples for the same person being mentioned by a Latin distinguishing element in one source and by one in the vernacular in another, cf. for example magistrum Lucachium dictum Nemeth 'Master Lucas called Német' (AO. 2: 457) and in Latin: magistro Lucachio theotonico castellano de Bolduaku 'to Master Lucas German, castellan of Boldogkö' (AO. 2: 572), cf. both Hun. Nemeth and Lat. theutonicus mean 'German'.

For the distinguishing elements of this period, we can only speak of a more or less consequent translating practice in that words which are part of the basic vocabulary of both languages (e.g. 'black', 'red', 'great') seem to have been translated more often than the ones requiring a more profound knowledge of Latin (a summary of this phenomenon see in N. Fodor 2010:28-29, Slíz 2011: 228-233). There are differences in translation according to the motivational type of the distinguishing elements: for those describing external characteristics, ethnicity or profession, about as many of them are translated as there are left untranslated, while Magyar 'Hungarian' is hardly ever translated. Names of animals, plants and objects are typically left untranslated, and so are those referring to actions or events. The reason for leaving these elements untranslated in some cases may be the fact that the Latin equivalent of two synonyms is the same and so translating these would obscure the difference between them, which could cause legal and economic conflicts, e.g. Hun. Veres/Piros vs. Lat. Rufus 'Red'; Hun. Kopasz/Tar vs. Lat. Calvus 'Bald'; Hun. Farkas/Ordas vs. Lat. Lupus 'Wolf'.

During the fourteenth century there were more and more cases when the same grammatical form in Latin and Hungarian would feature side by side, redundantly, e.g. with patronymics, the Hungarian suffix -é and Latin filius: Simon filius Balase 'Blaise's son Simon' (AO: 5: 87); or with place names, the Hungarian suffix $-i$ and the Latin preposition de: Beke filius Jacobi de Tenky 'Jacob Tenki's son Beke' (AO. 5: 385).

From the early sixteenth century on there are examples for the conscious differentiation between the inheritable and non-inheritable name types in tax registries using linguistic means, with Christian names given in their Latin equivalent, while family names originating in Christian name would as a rule be given in Hungarian. The order of the components would still follow the Latin and the Latin linking elements (filius, de, dictus, de genere) had by then completely vanished. See, for example, the full name Emericus [given name] $_{\text {Sebesthyen }}^{\text {[family name] }}$ (cf. Hun. Imre Lat. Emericus, Hun. Sebestyén Lat. Sebastianus; VeszprUrb. 22). It has to be noted, however, that the structure of family names featured in writing strongly depended on what type of source they appeared in (for more on this, see Slíz 2013). 
Farkas, Tamás and Mariann Slíz. "Translating Family Names in Hungarian: A Diachronic Survey.” Hungarian Cultural Studies. e-Journal of the American Hungarian Educators Association, Volume 6 (2013): http://ahea.pitt.edu DOI: $10.5195 /$ ahea.2013.114

\section{Spontaneous and Deliberate Changes: Humanists' Changes and Magyarization of Family Names}

Before the official registration of family names in the beginning of the nineteenth century, even otherwise inheritable family names could still change, motivated by a number of potential reasons stemming from changes in the individual's circumstances or characteristics, such as moving to another region, escaping from the estate to another squire, and receiving new lands from the monarch. In such cases name changes were usually not initiated by the individual but occurred spontaneously through community use. Although inheritable spontaneous name change was not very frequent during the seventeenth and eighteenth centuries, there are still ample examples for it in the sources, as the following categories of examples will illustrate.

Language contact situations occurring in a multilingual environment could also result in name changes, typically with the version of the name in the dominant dialect overwriting the original version. Thus, in Hungary, the most frequent type of change was the spontaneous Magyarization, but in certain regions where there was, for example, a Slavic majority, Hungarian names could be slavified as well, e.g. by taking the characteristic South Slavic -ić/-ič suffix (in Hungarian orthography): Márton > Mártonics, Varga > Vargaity (Mikesy 1963: 218). In the following, we give some examples of the more typical process of Magyarization.

Foreign family names could adapt to the characteristics of the Hungarian system of names in oral and written form through various processes (see Farkas 2009b, 2009c; for specific examples see also Mikesy 1963, Orosz 1989, Fülöp 2009, Mizser 2009, Fábián 2011, SzilágyiKósa 2011). The basic types, which could, of course, feature in any combination as well, are as follows:

(1) Change in the written form of the name: Ger. Schmidt > Smitt, Schwäbisch > Svébis; It. Finazzi > Fináczy.

(2) Change in the pronunciation, for example adding vowels to consonant clusters, which are uncharacteristic of Hungarian and therefore more or less hardly pronouncable, e.g. Slavic Kmetykó > Metykó, Tchor > Tihor; Ger. Schlegl > Slégli, Vindl > Vindel.

(3) Cutting off foreign-sounding endings and/or creating Hungarian-sounding endings, e.g. Slavic Sinkovics > Sinkó, Bajnovics > Bajna; It. Verocchio > Verók.

(4) Folk etymology, where the original meaning of a name is no longer understood and it becomes associated with a similar sounding but totally different meaning word in Hungarian e.g. Slavic Golgovszki ('from Golgova, Pozsega county, now in Croatia'> Galgóci ('from Galgóc, Nyitra county, now in Slovakia'); Ger. Raab 'Györ, a settlement name' > Rab 'prisoner', Lang 'long, tall' > Láng 'flame'.

(5) Translating the name, e.g. Slavic Mlinár > Molnár 'miller', Bili > Fehér 'white', Vásárhelyszki > Vásárhelyi 'from Vásárhely'. In the latter cases, however, it is virtually impossible to decide whether a name was actually translated or the person was given two different names in two languages based on the same characteristic (cf. Kázmér, 1981).

Through spontaneous name changes, however, any kind of family name could be replaced with any other kind of family name, not connected to it in any of the ways listed above. It means not the 'translation' of the original family name but the birth of a completely new name, which is based not on the original name but on a new type of motivation (e.g. personal characteristics, or place of earlier dwelling), thus these cases are outside the scope of this paper.

The types of spontaneous name changes listed above did not occur overnight but through continued and repeated use in a community, sometimes over the span of several generations, and sometimes with the name used in official documents supplanted eventually by the newer name, 
Farkas, Tamás and Mariann Slíz. "Translating Family Names in Hungarian: A Diachronic Survey.” Hungarian Cultural Studies. e-Journal of the American Hungarian Educators Association, Volume 6 (2013): http://ahea.pitt.edu DOI: 10.5195/ahea.2013.114

which had its origin in oral naming conventions. In multilingual communities, this process could have gone hand in hand with the process of language shift as well. Unlike the earlier Latinizing names in the medieval written language, the phenomena of spontaneous name changes came to play an active formative role in the history of the Hungarian family name stock and in the process of shaping its composition.

Not only spontaneous name changes, as described above, but also conscious family name changes have a history of several hundred years in Hungary. The first known chapter of such changes is the name choices made by humanist scholars in the sixteenth and seventeenth centuries, which involved translating a family name into a prestige language, usually Latin, and less frequently, Greek or Hebrew, e.g. Hun. Kovács 'smith' > Lat. [Faber >] Fábry, Hun. Molnár or Ger. Müller 'müller' > Lat. [Molitor >] Molitoris (cf. Kálmán 1989: 91).

Even though in the foregoing cases the names are translated into Latin, Greek or Hebrew, there are several differences between the circumstances of the two types of changes. With name choices made by humanists, it was typically the name bearer who translated the name into Latin, Greek or Hebrew, while with documents, it was the scribe who Latinized the names to be put into the text. The latter would be rather occasional, as opposed to the names of humanists, which would then be used to sign several works by the same author. The motivation behind humanist name changes was not to make it easier to incorporate the name into a Latin context, but to adapt it to the Latinate culture, considered pure and ideal - thus it can be seen as a phenomenon of simply a linguistic fashion, one that was also denounced as foreignizing by Ferenc Pápai Páriz, a contemporary author, vicar, doctor and teacher [1649-1716] (cf. Mikesy 1963: 219-20, H[ajdú] 1980: 92). Humanist Latinizing name changes were, of course, not restricted to Hungary but were a widespread European practice, and the Hungarian scholars who chose humanist names for themselves had studied or worked at European universities, and maintained correspondence with other humanists in Western Europe, felt that their Latinate names were more appropriate as well as more memorable and would gain their easier admittance to the community of European scholars (cf. Hajdú 2006: 257).

One such scholar who latinized his name was Zsámboky János (meaning 'from' + Zsámbok), who changed his name to Lat. Johannes Sambucus (Zsámboky/Sambucus studied at universities in Western Europe and became a professor at the university of Bologna, and later the court historiographer of the Habsburgs in Vienna). Another was Szamosközy István, a Transylvanian historiographer who worked mostly in Hungary and was also known internationally for his archeological work carried out in Padua, who changed his last name, meaning 'from' + Szamosköz region name to Lat. Zamosius. Yet another scholar was the historiographer, Baranyai Decsi János (cf. Decs settlement name and Baranya county name; Lat. Johannes Decius Barovius). To cite a non-Hungarian example, Johannes Müller von

Königsberg, the fifteenth-century German mathematician and astronomer, became world famous after his death under his name calqued in Latin as Regiomontanus, but was referred to as well in some later sources with the Hungarian version of his name, as Király Hegy János, meaning 'king + mountain + John' (cf. Borsa 1986: 168).

\section{The Magyarization of Family Names}

Let us next turn our attention to the Magyarization of family names of foreign origin in Hungary. In the nineteenth century the majority of name changes resulted in changing the language of the name as well - specifically, its entire point was in changing a foreign family 
Farkas, Tamás and Mariann Slíz. "Translating Family Names in Hungarian: A Diachronic Survey.” Hungarian Cultural Studies. e-Journal of the American Hungarian Educators Association, Volume 6 (2013): http://ahea.pitt.edu DOI: 10.5195/ahea.2013.114

name to get a Hungarian one. This process could be called 'nominal assimilation' (cf. Karády 2009) where the Magyarization of family names was closely linked with the process of family names becoming ethnic symbols. The conscious and purposeful nature of these changes only become obvious if we consider the ideological system of contemporary nationalism, which could have endowed a higher prestige to 'good' Hungarian names as opposed to the potential stigmatization of names of foreign origin, as well as of their bearers. The same period saw the similar Magyarization of place names of foreign origin as well in the country. The process of name Magyarization thus got understandably linked with the assimilation of certain social groups - the best known example being the changing of the German-sounding family names of Hungarian Jews (see Farkas 2012). Among the motives for name changes, the ethnic composition of Hungary between the mid-nineteenth and mid-twentieth century was especially important. Half of the population of the Hungarian Kingdom in the beginning of the twentieth century belonged to one of the minority groups in the country, with many members seeking to Hungarianize their names. In the interpretation of the course of the so called Name Magyarization movement the political, the social and the (language-)ideological context should be taken into account (for more on this, see Maitz \& Farkas 2008). As a result of several subsequent royal decrees, in the nineteenth century official permission was required for changing one's family name. Thus these name changes differed from earlier family name changes in this respect as well.

Apart from language-ideological considerations - and even independent of these - the question of using the foreign or the Hungarian family name was also linked with the problem of oral and written linguistic efficiency. A significant number of those who Magyarized their names gave the main motivation of choosing their new names the practical everyday difficulties they had encountered in having a name different in sound and spelling from the dominant language and its name system.

The majority of new Hungarian family names adopted in the nineteenth century show some kind of formal connection with the bearer's original name, most typically by keeping the initial letter, e.g. Slavic Drajkó > Drávai, Ger. Hubert > Harsányi, Hebrew Kohn > Kun. Less frequently, the name was fully or partially translated, e.g. Rom. Cimpian > Mezei 'of the field'; Ger. Nasch > Csemegi (csemege 'sweetmeat' + suffix -i), Steiner > Kövári 'from a stone castle'; Slavic Domszky > Hazai 'of home(land)', Bili > Fehér 'white'. These two main types of name change branched off into a number of degrees and subtypes, while in some cases the choice of the new name had other practical motivations behind it, such as place of origin, e.g. in the case of the great painter, Lieb Mihály > Munkácsy 'from Munkács', or, in the lack of any such consideration, it was based on just the name taste of the petitioner. (For more on this, see Farkas 2009c: 369-371.)

As opposed to the processes reviewed earlier, the use of new names adopted through official procedures was lasting and consequent in both oral and written communication, which is partly the result of the strict name use regulations instituted in this period. Finally, it is to be noted that conscious practices like the ones listed above can also be seen in the case of nonofficial name use, mainly for reasons of an artistic, academic or other 'public' career. The reasons and methods of this are similar to the official name changes, the main difference being that these names did not enjoy an official status and therefore could not be inherited, although some of them were later made official by their bearers and hence inheritable, such as the adopted name of Schedel > Toldy Ferenc, the father of Hungarian literary history, the name of the Orientalist Bamberger > Vámbéry Vámbéri Ármin, or the painter Lieb > Munkácsy Mihály. 
Farkas, Tamás and Mariann Slíz. "Translating Family Names in Hungarian: A Diachronic Survey.” Hungarian Cultural Studies. e-Journal of the American Hungarian Educators Association, Volume 6 (2013): http://ahea.pitt.edu DOI: $10.5195 /$ ahea.2013.114

\section{The Changes of Hungarian Family Names Outside of Hungary}

Hungarian family names used outside Hungary and thus outside the scope of Hungarian as an official language can be greatly influenced by the linguistic characteristics and the name systems of other languages. It happened to many of the family names of many of the Hungarians in the Carpathian Basin after World War I as they became the citizens of new countries that were established in the area of the former Austro-Hungarian Empire. Changes in the spelling (e.g. Kis > Slovakian Kiš; Márkus > Romanian Marcuş), in the writing system (e.g. Veres > Russian Bepeu), or the morphology of the name (e.g. Katona > Slovakian Katonová; Antal > Romanian Antalu) could change the original form of the name. The family names of the Hungarian minority groups were changed typically by the bureaucracy, in the written and oral communication of the state languages (Slovak, Romanian etc.), and were less typically based on a name-change petition of the name-bearer, i.e. the intentions of the individual. Their unintentional family name changes could be interpreted in the 'force field' they happen in, i.e. according to the politics, administration, legal aspects, official language and everyday language use of the given country.

The family names of Hungarian immigrants to the Unites States, to Western European countries or to Latin-America could be influenced in a similar way in the twentieth century. Their family names could have been more frequently changed consciously than in the countries of the Carpathian Basin, but the unintentional changes of the family names of the immigrants were not less typical.

Hungarian family names of those living outside the borders of Hungary could change in the official written language when entered in the birth, marriage or death registries, and in everyday oral use as well, by adapting more or less to the context of the dominant language. Considering the identity-expressing potential of personal names, such changes in name use can be linked with assimilation tendencies for the Hungarian minority groups of the Carpathian Basin and with integration strategies in the case of Hungarians in the diaspora - both as their tool and as their result (see Nogrady 1990; Bartha 1993; Fercsik 2004; Vörös 2004, 2012; Beregszászi \& Csernicskó 2011; Trunki 2013).

The most usual name changes for Hungarian names outside the borders of Hungary is transcribing the name to fit the orthographic system of the official language (especially by leaving the letters or accents only used in Hungarian and adding the corresponding letters and accents of the dominant language), e.g. in Slovakia Babcsány Babčañ, Csábi > Čábi, Szabó > $S a b o$, but orthographic changes can also be used to preserve as far as it is possible the original sound, as for instance in the US: Béres > Beresh, Csillag > Cillag, Gyurkó > Jurko, Major > Mayor.

The differences between the sound sets of the given languages can bring about further modifications, sometimes resulting in several possible versions of the same family name, e.g. in Romania: Füstös > Fistoş $\sim$ Fustes; Fekete > Fechet $\sim$ Fechetă $\sim$ Fichitiu. In Ukraine, the transliteration into Cyrillic makes the process even more complex, resulting in a multitude of versions: Sütö $>$ Шітев $\sim$ Шитев $\sim$ Шютев $\sim$ Шютов $\sim$ Шюте $\sim$ Шити. The very same name can change to adapt to different linguistic contexts in different ways, e.g. the Hungarian family name Géczy Géczi can become Gatesy in the U.S. and Гещฺи Гейци in Ukraine in the old Russian tradition of transliteration and Геці $\sim$ Гейці in the Ukrainian transliteration.

Hungarian family names can be subject to morphological changes as well. In Slovakia, family names of women take the feminine ending, which is a practice unknown in Hungarian language use (cf. Misad 2012, in this journal). E.g. Szabó + -ová > Szabóová Sabová; 
Farkas, Tamás and Mariann Slíz. "Translating Family Names in Hungarian: A Diachronic Survey.” Hungarian Cultural Studies. e-Journal of the American Hungarian Educators Association, Volume 6 (2013): http://ahea.pitt.edu DOI: 10.5195/ahea.2013.114

Presinszky Presinszká (the latter being a family name of Slavic origin but if the bearer is Hungarian, taking the feminine suffix can be considered a name change). The phenomena listed so far are typically changes occurring independent of the intentions of the name bearer, first of all brought about in the practice of the authorities (official registrations etc.) of the given state. The complete change or translation of the family name, however, can only be the result of a conscious individual decision. To give Hungarian examples from the U.S. and Canada, Szakács 'cook' > Cook, Jakab 'Jacob' > Jacobs; or even Kovács 'smith' > Stephenson, not willing to simply translate his name, perhaps to avoid the frequency of the English equivalent.

The most extreme example of local authorities forcing the changing of Hungarian family names is the practice of the recent past in Slovakia that required not only spelling Hungarian family names of historic persons according to Slovakian orthography (e.g. Rákóczi > Rákoci, Pázmány > Pazmán̆), but also translating names that originated from historical Hungarian place names of settlements that belong to Slovakia today (e.g. Kubinyi > Kubinský, Szentiványi > Svätojánský, Görgei > Harhovský). Such a legal requirement, however, is obviously beyond the usual questions of the translatability of personal names and belongs to the field of (language) politics (for more see Vörös 2004: 38-41).

In minority communities, the changes of the names can result in an individual having several names or the phenomenon of the so-called name alternation. Hungarians in Slovakia, for example, might use the official form of their personal name in official Slovak contexts, while in informal Hungarian contexts - oral or written - they have recourse to its Hungarian equivalent, e.g. Hun. Kincses József Slovak Jozef Kinčeš, Hun. Presinszky Jánosné Slovak Anna Presinszká (Vörös 2009). These name variants show that the speakers consider the components of these name pairs to belong not only to different registers, but also specifically to one or the other language and culture.

The name changes mentioned here are also linked to the questions of language rights. In Hungary and the neighboring countries today it is possible to register personal names according to the orthography of the bearer's mother tongue. But if a foreign citizen of Hungarian ethnicity is going to supply the original form of his/her original Hungarian family name, it cannot always be readily reconstructed from the form used in the official language of the country in which he/she lives. For example, if someone from the Carpathian region of Ukraine and has Bepeu for a family name, it can have Veres $\sim$ Veress $\sim$ Vörös $\sim$ Weöres behind it as the original Hungarian form, while a Гiмemi can be Gimesi Gyimesi or Himesi, and it is also unclear how obvious a connection there is between the name Gyrykh, arrived at by the regular transliteration of the official Ukrainian version and the original Hungarian family name Görög.

The question of transmitting Hungarian family names from one language and/or writing system to another has only recently begun to receive more scholarly attention. However, this chapter is also part of the history of Hungarian family names and not only in the context of Hungarian communities outside Hungary but also the name using practices of today's Hungary.

\section{The Translation of Fictional Family Names of Foreign Origin in Literature and Film}

The translatability of family names featured in films and literature raises some special questions. Authors usually choose the names of characters with great care and attention, as names add to the impression created by their bearers and characterize them in some way or another. It can be the name's sound or spelling which is important, or its being typical or atypical in the given social context. The most directly characterizing names are the so-called "speaking 
Farkas, Tamás and Mariann Slíz. "Translating Family Names in Hungarian: A Diachronic Survey.” Hungarian Cultural Studies. e-Journal of the American Hungarian Educators Association, Volume 6 (2013): http://ahea.pitt.edu DOI: 10.5195/ahea.2013.114

names," whose meaning as common nouns is transparent and has some kind of link to the characters who wear them (cf. Kovalovszky 1934).

When translating family names, the Hungarian translator has two guidelines to bear in mind. First, family names in fiction of foreign languages are not translated in the Hungarian translation tradition because it would do away with their potential in characterizing through their language and/or ethnicity. Second, the name should keep as much of the original information encoded in it by the author as possible. These two principles, however, often contradict each other.

It is the translator's task to come up with some kind of a solution to this problem, but by now there is a certain widespread practice that translators usually follow when making decisions. This implies that names of characters living in 'real life' worlds are normally not translated, even when it means losing certain amount of information encoded in the name. Thus for instance characters in Jane Austen's Emma are called Mr. Knightly and Miss Woodhouse in the Hungarian versions as well. One solution for retaining the original information given by the English names is providing translator's footnotes giving the meaning of the names, which is rarely used, but applied, for example, in one of the several Hungarian translations of Dickens' Little Dorrit, translated as Lenke Bizám (Budapest: Lazi Kiadó, 2010). However, there are exceptions to the rule of not translating the names of characters living in real life worlds. These exceptions pertain in the following cases: (1) The character is a real historic figure whose name is traditionally translated into Hungarian in other contexts as well (e.g. Calvin Kálvin). (2) Intertextuality: the name of the character has been translated in another work or a prequel to the given text, e.g. Louis de Funès plays a gendarme character in some of his films called Cruchot, who got to be called Lütyö in the Hungarian version to reflect the comic sound of the original name. Once a translator made this decision when translating the first film featuring the character, later translations have to use the same name to make him identifiable for the audience. (3) In comic genres speaking names get to be translated more often, to keep the humorous effect, as in the case of Cruchot or Basil Fawlty in the BBC's Fawlty Towers series, called Mr. Waczak 'faulty', written with a likewise foreign and/or archaic spelling. (4) If a Hungarian character features in a work of fiction whose name is spelled with a non-Hungarian orthography, e.g. the Hungarian characters of Jules Verne's novels. One of these novels, Mathias Sandorf, features its Hungarians in the French original as Mathias Sandorf, Etienne Bathory, Ladislas Zathmar, Silas Toronthal, but to make them authentic for the Hungarian audience, the translators 'corrected' the form or the spelling of these names (and also gave the characters a credible-sounding Hungarian given name, and reconstructed the Hungarian family name + given name order), making them appear as Sándor Mátyás, Báthory István, Szathmár László, Torontál Simon. In Verne’s The Danube Pilot there is also a supposedly Hungarian character, called Ilia Brusch in French, referred to in subsequent Hungarian translations as Brusch Ilia or Borus Demeter. In the latter the family name is a replacement of the original with a similar-sounding, existent Hungarian family name. The spelling of two other characters, Dragosh and Jaeger in the original novel was also changed to suit their 'Hungarian' equivalents that both exist in the Hungarian name stock (even if of foreign origin), resulting in Dragos(s) and Jäger. (5) Adhering to an existent translation tradition: the name of the main character of Verne's Michel Strogoff, set in Russia, would be spelled Sztrogov according to today's transliteration rules from Cyrillic, but yet to continue the tradition of earlier translations and the 'identity' of the character, later Hungarian editions kept the version created by the first translator, Sztrogof (see Farkas 2011: 112-114). 
Farkas, Tamás and Mariann Slíz. "Translating Family Names in Hungarian: A Diachronic Survey.” Hungarian Cultural Studies. e-Journal of the American Hungarian Educators Association, Volume 6 (2013): http://ahea.pitt.edu DOI: 10.5195/ahea.2013.114

As for the characters in stories set in fictitious, made-up worlds, like fairytales or fantasy novels, they are treated much more freely by Hungarian translators. Among the considerations we find whether the sound of the name is important in itself and whether the reference made by the original name would be understandable by the Hungarian audience. J.K.Rowling's Albus Dumbledore kept his name in the Hungarian version of the Harry Potter series, because the translator considered it more important to keep the sound of the name than to convey its meaning (which is obsolete in modern English anyway). Minerva McGonagall, on the other hand, kept her first name, while her family name was changed to McGalagony, from Hun. galagonya 'yew', which retains the internal alliteration of the original name, but also preserves its Scottish (thus British) character. Meanwhile the name of Godric Gryffindor was changed for Griffendél in the Hungarian translation, losing its obvious French (and thus medieval British) meaning and connotation that it had for the English readers, while becoming more English/British sounding for the Hungarian readers (for more detail on this see Hertelendy 2011). Many of the family names of the Hobbits in J.R.R. Tolkien's The Lord of the Rings were translated in the Hungarian edition as if they were transparent speaking names in the original, e.g. Baggins Zsákos 'bags', Proudfoot Csülök 'trotters'. In George R.R. Martin's fantasy cycle A Song of Fire and Ice, the family names of the characters were left untranslated even if their meaning was transparent (e.g. Stark, Greyjoy), while the transparent surnames of the bastards were translated (e.g. Snow Havas 'snowy', Flowers Virágos 'flowery'). By this differentiation the translator wished to convey the fact that these are not actual inherited family names but names automatically given to all the bastards who come from a given region, which signals not only their native region but also their status as bastards. These names are closer to the nicknames of other characters, which also got translated (e.g. Qhorin Halfhand Félkezü Qhorin) than to family names. The decision might also depend on what kind of creature we are talking about. In Rowling's Harry Potter series, the names of the wizards' world - that is, the names of many of the wizards and magical creatures - were mostly translated in the Hungarian version, unlike the names of muggles, whose names thus convey the characteristic English milieu as well. The names of the three main characters are likewise left untranslated, to emphasize also the fact that they are ordinary everyday children who the readers can easily identify with. (Harry Potter could have been, but was not, translated as Fazekas, Gerecsér or Gölöncsér Henrik; cf. Horváth 2008: 38.)

In the case of a series or a new translation of an already translated work, the name of the same character might be translated in different ways either because a new translator continued the work or because the motivation of name giving becomes transparent only at a later point in the story. An example from Terry Pratchett's Discworld characters is the name of Lady Sybil Ramkin, called Lady Koshfy Sybil and Lady Sybil Juhossy in two different volumes: kos 'ram' + suffix $-f i, j u h$ 'ewe' + suffixes $-s+-i$, with their morphology and archaic orthography considered typical for the names of nobility.

\section{Conclusion}

In our paper we wished to provide an overview of some theoretical and practical aspects of the translatability of family names in the history of the Hungarian language, using 'translation' in the wider sense to mean the transfer between languages and cultures. The main focus of our attention was on the different ways multilingualism, language contact situations, prestige considerations, customs, fashions and other potential factors affect the use of these names in various languages, as well as on translatability in the wider sense in the practice of family name use in Hungary, and on the use of Hungarian family names in other countries. We looked at the 
Farkas, Tamás and Mariann Slíz. "Translating Family Names in Hungarian: A Diachronic Survey.” Hungarian Cultural Studies. e-Journal of the American Hungarian Educators Association, Volume 6 (2013): http://ahea.pitt.edu DOI: 10.5195/ahea.2013.114

history of family name use in Hungary from the name translation practice found in medieval decrees, spontaneous name changes, conscious name changes in the humanist period and the phenomenon of official family name changes. As for more recent phenomena, we touched upon the changes affecting Hungarian family names in minority communities. We also analyzed the problems of the translatability of family names in various genres of fiction. The overview of this topic hopefully sheds light on certain aspects of Hungarian language use and social history, while also illustrating how - and in how many different ways - specific social, historic and socio-psychological circumstances leave their trace on the history of the use of Hungarian names and even on the name stock of our days.

\section{Works Cited}

AO. = Nagy, Imre. ed. 1878-1891. Anjoukori okmánytár [Collection of Documents from the Angevin Era.] Vol. 1-6. Budapest: MTA. Gyula Tasnádi Nagy, ed. 1920. Vol. 7. Budapest: MTA.

Bartha, Csilla. 1993. "Családnév-módosítások a detroiti magyarban [The Modifications of Surnames of Hungarians in Detroit]." Névtani Értesitö 15: 41-44.

Beregszászi, Anikó \& István Csernicskó. 2011. “A kárpátaljai magyar személynevek átírásának és használatának kérdésköréről [The Problems of Transliteration and Use of Personal Names of Subcarpathian Hungarians]." Magyar Nyelvör 135: 414-422.

Borsa, Gedeon. 1986. "A Csízió históriája [The History of Csízió]." In Csízió vagyis a csillagászati tudománynak rövid és értelmes leírása. Budapest: Mezőgazdasági Kiadó: 165171.

Fábián, Zsuzsanna. 2011. "Olasz családnevek Magyarországon [Italian Surnames in Hungary]." In Ferenc Vörös, ed. A nyelvföldrajztól a névföldrajzig II. Családnév-helynév-kisebbségek. Szombathely: Savaria University Press: 79-94.

Farkas, Tamás. 2009a. "A tulajdonnevek fordításának alapkérdéseiröl. Diadal vagy Viktória, Eugén vagy Jenö? [On Basic Questions of Translating Proper Names. Diadal or Viktória, Eugén or Jenö?]" Fordítástudomány 11.2: 22-35.

Farkas, Tamás. 2009b. "Családnévrendszer, névhasználat, névváltozás nyelvi-kulturális kontaktushelyzetben [The System of Family Names, Their Use, and Changes to them in a Linguistic-Cultural Contact Situation].” Névtani Értesitö 31: 27-46.

Farkas, Tamás. 2009c. "Surnames of Foreign Origin in a Language Contact Situation. The Reasons and Ways of Their Changes and Their Influence on the Surname Stock in Hungary." In Wolfgang Ahrens, Sheila Embleton \& André Lapierre, eds. Names in Multi-Lingual, MultiCultural and Multi-Ethnic Contact. Proceedings of the 23rd International Congress of Onomastic Sciences. August 17-22, 2008, York University, Toronto, Canada. Toronto: York University: 365-374.

Farkas, Tamás. 2011. "Franciás müveltség, magyar nyelv és a tulajdonnevek fordítása [French Civilization, Hungarian Language and the Translation of Proper Names]." In Gábor Csiszér \& Anikó Darvas, eds. Klárisok. Tanulmánykötet Korompay Klára tiszteletére. Budapest: Magyar Nyelvtörténeti, Szociolingvisztikai, Dialektológiai Tanszék: 109-116.

Farkas, Tamás. 2012. "Jewish Name Magyarization in Hungary." AHEA 5. http://ahea.net/ejournal/volume-5-2012/34.

Fercsik, Erzsébet. 2004. "Személynevek megváltozott nyelvi és kulturális környezetben - A külföldön élő magyar fotográfusok névhasználatáról [Personal Names in a Changing 
Farkas, Tamás and Mariann Slíz. "Translating Family Names in Hungarian: A Diachronic Survey.” Hungarian Cultural Studies. e-Journal of the American Hungarian Educators Association, Volume 6 (2013): http://ahea.pitt.edu DOI: 10.5195/ahea.2013.114

Linguistic-cultural Contact Situation. On the Use of Personal Names of Hungarian Photographers Living Abroad]." Névtani Értesitő 26: 57-66.

N. Fodor, János. 2010. Személynevek rendszere a kései ómagyar korban. A Felsö-Tisza-vidék személyneveinek nyelvi elemzése (1401-1526) [System of Personal Names in the Late Old Hungarian. Linguistic Analysis of Personal Names from the Upper Tisza Region (1401 1526).] Magyar Névtani Értekezések 2. Budapest: ELTE Magyar Nyelvtudományi és Finnugor Intézet.

Fülöp, László. 2009. "Névváltozások és névváltoztatások Kaposvár környékén a 19. Században [Changes of Names and Name Changes in the Vicinity of the Town of Kaposvár in the Nineteenth Century].” In Tamás Farkas \& István Kozma, eds. A családnév-változtatások történetei időben, térben, társadalomban. Budapest: Gondolat Kiadó \& Magyar Nyelvtudományi Társaság: 205-214.

H[ajdú], M[ihály]. 1980. "Pápai Páriz Ferenc névtani megfigyelései [The Onomastic Notes of Ferenc Pápai Páriz]." Névtani Értesítő 4: 89-92.

Hajdú, Mihály. 2006. “Álnév - fedőnév - jelige - internetnév [Pseudonym - Code-name - Motto - Nickname].“ In Attila Mártonfi, Kornélia Papp \& Mariann Slíz, eds. 101 írás Pusztai Ferenc tiszteletére. Budapest: Argumentum Kiadó: 257-266.

Hertelendy, Réka. 2011. "Fordítói kihívások és megoldások a magyar nyelvü Harry Potterkötetekben [Challenges and Solutions in Translating the Harry Potter Volumes into Hungarian]." Névtani Értesítö 33: 133-145.

Horváth, Péter Iván. 2008. "Személynevek a szakfordításban [Personal Names in Technical Translation]." Névtani Értesitó 30: 35-40.

Kálmán, Béla. 1989. A nevek világa. [The World of Names.] Budapest: Csokonai Kiadó.

Karády, Viktor. 2009. “A névmagyarosítások társadalomtörténeti összefüggései [Socialhistorical Relations of Name Magyarizations].” In Tamás Farkas \& István Kozma, eds. A családnév-változtatások történetei időben, térben, társadalomban. Budapest: Gondolat Kiadó \& Magyar Nyelvtudományi Társaság: 41-55.

Kázmér, Miklós. 1981. “A párhuzamos személynévadás [Parallel Personal Naming].” In Mihály Hajdú \& Endre Rácz, eds. Név és társadalom. A III. Magyar Névtudományi Konferencia elöadásai. A Magyar Nyelvtudományi Társaság Kiadványai 160. Budapest: Magyar Nyelvtudományi Társaság: 43-46.

Kovalovszky, Miklós. 1934. Az irodalmi névadás. [Name-giving in Literature.] A Magyar Nyelvtudományi Társaság Kiadványai 34. Budapest: Magyar Nyelvtudományi Társaság.

Maitz, Péter and Tamás Farkas. 2008. "Der Familienname als Nationalsymbol. Über den Untergang deutscher Familiennamen im Ungarn des 19. Jahrhunderts [The Family Name as a National Symbol. The Decline of German Family Names in Hungary in the Nineteenth Century]." Zeitschrift für germanistische Linguistik 36: 163-196.

Mikesy, Sándor. 1963. "A névszépítésröl [On the Retouching of Names].” Magyar Nyelv 59: 216-221.

Misad, Katalin. 2012. "The Characteristics of Hungarian Women's Names in Slovakia.” AHEA 5. http://ahea.net/e-journal/volume-5-2012/37

Mizser, Lajos. 2009. “A nyíregyházi tirpákok névváltoztatásai [Name Changes of the Tirpáks in the Settlement of Nyíregyháza].” In Tamás Farkas \& István Kozma, eds. A családnévváltoztatások történetei időben, térben, társadalomban. Budapest: Gondolat Kiadó \& Magyar Nyelvtudományi Társaság: 215-221. 
Farkas, Tamás and Mariann Slíz. "Translating Family Names in Hungarian: A Diachronic Survey.” Hungarian Cultural Studies. e-Journal of the American Hungarian Educators Association, Volume 6 (2013): http://ahea.pitt.edu DOI: 10.5195/ahea.2013.114

Nogrady, Michael. 1990. "Treatment of Hungarian Names in Canada.” In Jean-Claude Boulanger, ed. Proper Names at the Crossroads of the Humanities and Social Sciences. Proceedings of the XVIth International Congress of Onomastic Sciences. Québec, Université Laval. 16-22 August 1987. Québec: Université Laval: 433-440.

Orosz, Béla. 1989. “A névváltoztatásokról [On Name Changes].” In: Lajos Balogh \& Ferenc Ördög, eds. Névtudomány és müvelödéstörténet. A IV. magyar névtudományi konferencia előadásai. A Magyar Nyelvtudományi Társaság Kiadványai 183. Budapest: Magyar Nyelvtudományi Társaság: 252-255.

Slíz, Mariann. 2011. Személynévadás az Anjou-korban. [Personal Naming in the Angevin Age.] Budapest: Históriaantik.

Slíz, Mariann. 2013. "The role of the type of sources in historical family name studies." In Oliviu Felecan, ed. Proceedings of the Second International Conference on Onomastics "Name and Naming". Onomastics in Contemporary Public Space. Cluj-Napoca: Editura Mega, Editura Argonaut. In print.

J. Soltész, Katalin. 1979. A tulajdonnév funkciója és jelentése. [The Function and Meaning of Proper Names.] Budapest: Akadémiai Kiadó.

Szilágyi-Kósa, Anikó. 2011. Ungarndeutsche Personennamen im Plattenseeoberland. Eine anthroponomastische Langzeitstudie in Deutschbarnag/Barnag und Werstuhl/Vöröstó [German Personal Names in the Balaton Uplands in Hungary. A Study of Historical Anthroponomastics in Barnag and Vöröstó]. Ungarndeutsches Archiv 11. Budapest: ELTE Germanistisches Institut.

Trunki, Péter. 2013. “A moldvai magyarok mai családnevei a magyar állampolgárság küszöbén [Present-day Family Names of Hungarians in Moldavia on the Threshold of Hungarian Citizenship]." Magyar Nyelv 109: 107-116.

Vermes, Albert Péter. 2005. Proper names in translation: a relevance-theoretic analysis. Debrecen: Debreceni Egyetem Kossuth Egyetemi Kiadója.

VeszprUrb. = Kredics, László and László Solymosi. 1993. A veszprémi püspökség 1524. évi urbáriuma [Urbarium of the Veszprém Episcopate from 1524]. Új Történelmi Tár. Fontes Minores ad Historiam Hungariae Spectantes 4. Budapest: Akadémiai Kiadó.

Vörös, Ferenc. 2004. Családnévkutatások Szlovákiában [Family Name Researches in Slovakia]. Csallóközi Kiskönyvtár. Pozsony: Kalligram Könyvkiadó.

Vörös, Ferenc. 2009. "Névváltoztatás és névhelyreállítás a kisebbségi magyar nyelvhasználat tükrében: terminológiai javaslat egy névtani jelenség megnevezésére [Name Change and Name Reconstruction in the Name Use of Hungarian Minorities: Terminological Proposal for Identifying an Onomastic Phenomenon].” In Tamás Farkas \& István Kozma, eds. A családnév-változtatások történetei időben, térben, társadalomban. Budapest: Gondolat Kiadó \& Magyar Nyelvtudományi Társaság: 57-74.

Vörös, Ferenc. 2012. "Személynévhasználat és impériumváltások a 20. századi Kárpátalján [The Use of Personal Names and Regime Changes in Twentieth-century Subcarpathia]." Magyar Nyelvőr 136: 78-88. 